\title{
IMPERIALISMO E EDUCAÇÃO
}

\author{
Francisco Máuri de Carvalho Freitas ${ }^{i}$
}

\section{RESUMO:}

$\mathrm{Na}$ atual quadra política da República brasileira se a educação oficial não está voltada à construção de uma nova sociedade, sem classes, então o trabalho pedagógico tem por objetivo consolidar o poder da burguesia. Os intelectuais da ordem reforçam a ação dos aparelhos repressivos e ideológicos de Estado. A densidade política do imperialismo reclama a feitura de análises acuradas quanto às modernas modificações mundiais empreendidas contemporaneamente pelo capitalismo. Para tanto é preciso observar no desenvolvimento deste modo de produção as alterações sofridas no início do século XXI, antecipadas por Lenin já no alvorecer do século XX: domínio da vida econômica pelos monopólios, criação do capital financeiro especulativo e da oligarquia financeira, predomínio da exportação de capitais, em detrimento da exportação de mercadorias, fusão de grandes empresas, partilha do mundo em áreas extrativistas entre as sete maiores e mais poderosas potências capitalista, sob comando norte-americano. Essas características são consubstanciadas hoje pela ideologia neoliberal, proclamada como apoteose de novidadeiras formulações teóricas do capitalismo sobre a possibilidade de elevar a condição de vida do proletariado e dos trabalhadores assalariados para patamares invejáveis ao mais rigoroso teórico marxista. Sob o ponto de vista da tradição marxista é inquestionável que o capitalismo alcançou sua forma superior de desenvolvimento e para sobreviver e exercitar-se de forma imperial, precisa se expandir e para isto necessita abocanhar outras regiões e países do globo terrestre. O imperialismo é a marca decisiva e absoluta que diferencia os séculos XX e XXI dos demais séculos antecedentes. Diante deste fato, é objetivo do presente estudo reportar não existir uma escola à margem da vida, à margem da política, sendo a afirmação contrária falsidade e hipocrisia. $\mathrm{Na}$ cidade do capital, o local por excelência da política é o Estado. Logo, a tarefa da crítica é afirmar que construção de um projeto pedagógico escolar à superação do capitalismo, "é ontologicamente impossível sem a própria superação do capital". Todas as tentativas de desenvolver uma política transformadora por intermédio da educação escolar acabam prisioneiras dos mesmos limites que tornam a sociabilidade burguesa e a sociabilidade operária incompatíveis entre si. Enfim, na cidade do capital os discursos da esquerda montados sob categorias abstratas e universais, apenas demonstra que a esquerda perdeu de vista os valores éticos classistas, sua natureza política e, não raro, perdeu a própria vergonha. Este fato não nos deixa alternativa senão trabalhar no sentido de construir uma outra esquerda, baseada nos princípios classistas e na tradição histórica do marxismoleninismo.

Palavras-chave: Educação. Marxismo. História. Imperialismo. Partido Comunista.

\section{IMPERIALISME ET ÉDUCATION}

\section{RÉSUMÉ:}

Si dans l'actuelle République brésilienne l'éducation ne se tourne pas vers la construction d'une nouvelle société, sans classes, alors le travail pédagogique a comme but d'affermir le pouvoir de la bourgeoisie. Les intellectuels de l'ordre renforcent les appareils idéologiques 
et répressifs de l'état.La densité politique de l'impérialisme rend nécessaire la réalisation d'analyses approfondies quant aux modernes modifications mondiales accomplies par le capitalisme. Pour cela il faut observer le développement de ce mode de production avec les altérations éprouvées en ce début de XXI ème siècle, déjà anticipées par Lénine à l'aube du XX ème siècle: domination de la vie économique par les monopoles, Création d'un capital financier spéculatif et d'une oligarchie financière, prédominance de l'exportation de capitaux en détriment de l'exportation des marchandises, fusion des grandes entreprises, répartition du monde en pôles d'extraction partagés par les sept grandes puissances sous la hégemonie des Etats Unis d'Amerique. Ses caracteristiques, formalisées aujourd'hui par l'ideologie neoliberale sont proclamées comme l'apotheose des nouvelles formulations theoriques du capitalisme sur la possibilité d'amelioration des conditions de vie du proletariat et des travailleurs salariés a des niveaux qui fairaient envie au plus rigoureux des téoriciens marxistes. Sous le point de vue de la tradition marxiste il est indeniable que le capitalisme a atteint sa forme superieure de developpement, et pour survivre et exercer son pouvoir imperial il a besoin de se propager s'accaparant d'autres regions et pays du globe. L'Imperialisme est la marque decisive et absolue qui differencie le XXème et le XXIème siècles des siècles precedents. Cela dit, l'objectif de cet etude est montrer qu'il n'existe pas d'école en marge de la vie, en marge de la politique, toute affirmation en contraire etant un faux et une hypocrisie. Dans la ville du capital le lieu par excellence de la politique c'est l'État. Donc, la tache de la critique é de proposer un projet pedagogique pour l'école conduisant au depassement du Capital.Toutes les tentatives de developper une politique transformatrice par le biais de l'education tombent prisonières des mêmes limites qui rendent la sociabilité bougeoise et la sociabilité ouvrière inconciliables. Enfin, dans la ville du Capital les discours de la gauche fondés surr des sur abstraites et universelles ne demontrent que la gauche a perdu de vue ses valeurs etiques de classe, sa nature politique et, souvent, la propre dignité. Ce fait ne nous laisse alternatives que celle de travailler pour la construction d'une autre gauche, fondée sur les principes de classe et dans la tradition historique du Marxisme-Leninisme.

Mots-Clés: Éducation. Marxisme. Histoire. Imperialisme. Parti Communiste.

\section{Intróito}

É "um direito nosso mudar, mas é um dever ético nosso assumir que mudamos. É desonesto mudar querendo enganar, afirmando que somos os mesmos!".

A troca da ditadura civil-burocrática-militar (1964-1985) por uma ditadura civilburocrática $^{\text {ii }}$ (1985 aos dias de hoje), sob a proteção armada dos militares, revela o passado e o presente desta Nação marcados pelos cesarismo, pela intransigência, abandono de princípios e traições hediondas. Um país cuja base econômica é o capital financeiro e a grande propriedade exportadora controladas por uma classe dominante para quem o adjetivo de mantenedora da escravidão assalariada não é força de expressão, suas forças conservadoras e reacionárias não poderiam agir de outro modo senão se erguendo com todas as armas contra quaisquer resquícios de resistência.

Nesta quadra política da República brasileira se a educação oficial não está voltada à construção de uma nova sociedade, sem classes, então o trabalho pedagógico tem por objetivo consolidar o poder da burguesia. Os intelectuais da ordem reforçam a ação dos aparelhos repressivos e ideológicos de Estado. Daí se dizer que "a escola à margem da vida, à margem da política, é falsidade e hipocrisia". iii

Escola e política ou a escola política. 
Se não existe escola à margem da vida, à margem da política e toda afirmação em contrário é falsidade e hipocrisia, é porque na cidade de classes, cidade do capital, o local por excelência da política é o Estado. Entretanto, de forma lastimável, no seio da esquerda em geral

Predomina a noção aristotélica: o homem como um animal político. A
maior debilidade desta definição está em que iguala o que é
ontologicamente distinto: a organização de uma sociedade de classes e a
organização de uma sociedade sem classes. Ela é incapaz de refletir a
qualidade específica da relação de dominação entre os homens, que é
uma das determinações mais importantes das sociedades de classes. Por
isso a concepção aristotélica e suas variantes, que fazem da política uma
dimensão universal do ser social, afirmam também a universalidade do
Estado e do Direito. E, por essa razão, são concepções que nem sequer
podem conceber a transição para uma sociedade comunista, isto é, uma
nova forma de organização social incompatível com o Estado, com o
Direito, com a propriedade privada e, portanto, com a política. ${ }^{\text {iv }}$

É tarefa da crítica afirmar que nenhuma teoria da educação ou pedagogia, nenhum projeto pedagógica escolar pode pretender a efetivação de valores éticos como precondição para superação do capitalismo, "pela simples razão de que esta efetivação é ontologicamente impossível sem a própria superação do capital". " De maneira que toda tentativa de desenvolver uma política transformadora por intermédio da educação escolar termina, na melhor das hipóteses, prisioneira dos mesmos limites que tornam a sociabilidade burguesa e a sociabilidade operária incompatíveis entre si.

Quando nas condições da cidade do capital perversa e excludente a esquerda busca fundamentar seu discurso em valores éticos universais, é porque ela perdeu de vista os valores éticos classistas sobre os quais deveria pautar sua conduta política, sua própria natureza de esquerda e, não raro, perdeu a própria vergonha. Este fato não nos deixa alternativa senão trabalhar no sentido de "construir uma outra esquerda, baseada nos princípios classistas e na tradição histórica do marxismo revolucionário" vi

Uma outra esquerda para quem sob a lei concorrencial do capitalismo imperialista ainda não superada, algumas conseqüências são inevitáveis dentre elas o "enriquecimento da minoria de indivíduos e o empobrecimento da classe operária e dos trabalhadores assalariados urbanos e rurais". vii Atento à marcha do capitalismo neste país sob a ideologia neoliberal, descobre-se como trágica a situação da vida dos camponeses pobres sem-terra compelidos a assumir a condição de trabalhadores assalariados nos mais diversos estabelecimentos de comércio e nas indústrias dos afortunados capitalistas.

Descobre-se que o desenvolvimento do capitalismo é paradoxal, de um lado, o inexorável empobrecimento dos trabalhadores urbanos e rurais, o decrescer do consumo per capita, o recrudescer da extorsão da força de trabalho aos níveis de mais-valia absoluta, enquanto cresce o mercado para o deleite de minorias dissolutas. $\mathrm{O}$ empobreceimento dos trabalhadores longe de representar um obstáculo ao desenvolvimento do modo de produção capitalista, expressa seu desenvolvimento e, por ser sua condição, o fortalece.

Nos marcos do capitalismo em escala planetária, o empobrecimento ocorre ininterruptamente à medida que os meios de produção permanecem concentrados nas mãos de uma mínima minoria que converte em capital os produtos criados submetidos ao mercado como "valor de troca". viii

Glosas marginais sobre a globalização 
A análise da dinâmica do capitalismo contemporâneo, também conhecido por "globalização", um eufemismo de imperialismo, torna atual uma tese defendida por Lenin no dealbar do século $\mathrm{XX}$, segundo a qual pari passu com a redução do número de capitalistas usurpadores de todas as vantagens do modo de produção em curso, "há o aumento massivo da miséria, da opressão, da escravidão, da degradação e da exploração". ix

Vários são os movimentos sociais que declaram ser a "globalização" ou "mundialização do capital" o principal inimigo da humanidade. Há que se tomar cuidado quanto ao que se deve entender por "globalização" ou "mundialização do capital", posto que neste contexto vemos reunidas, por exemplo, o José Bové, chefe de uma associação de agricultores franceses e o prêmio Nobel da literatura José Saramago. Que razões produzem a união de personalidades tão díspares contra a "globalização", de quê?

Sobre o significado conceitual do processo político e econômico precitado e alcunhado de "globalização", uma espécie de falsidade ideológica, devo dizer que esse verbete (globalização) é quase sempre seguido do adjetivo neoliberal ou capitalista ou, ainda, imperialista predatório. No Brasil há um pendor acentuado pelo eufemismo, pelo oximoro $^{\mathrm{x}}$ e pela hipérbole ${ }^{\mathrm{xi}}$. "Globalização" neoliberal e imperialismo predatório são oximoros, apenas decodificados se vistos como hipérboles do tipo "globalização capitalista" e "globalização imperialista", hipérboles de capitalismo e imperialismo. Por que se hiperboliza o capitalismo, atribuindo-lhe a condição e o porte físico de um moderno gigante Adamastor?

"Globalização" ou "mundialização do capital" são eufemismos daquilo que Lenin classificou como Imperialismo, o estágio superior do capitalismo. Por que razão então os que são contra a globalização não se autodesignam de anticapitalistas ou antiimperialistas?

Certamente, porque nem todos os que pertencem aos movimentos sociais contra a "globalização" são anticapitalistas, apenas alguns poucos se consideram marxistas e pouquíssimos são leninistas, a maioria (incluindo uma gama enorme de ex-marxistas e neomarxistas: eufemismos de revisionismo e fisiologismo) nunca leu Lenin, desconhece, portanto, a genealogia política e ideológica das idéias que supostamente abraçou e que algum dia disse defender.

Sem dúvidas, poucos, pouquíssimos leram a obra de Lenin precitada, até a aprovaram no varejo, mas depois da implosão do Estado soviético, acharam não ser lá muito aconselhável enaltecer as idéias de Lenin, por esta razão preferem eufemismos e oximoros: no lugar de político, social; no lugar de Partido, movimento; no lugar de revolução, reformas; para substituir o anticapitalismo, a anti-globalização e assim por diante.

"Globalização" e "mundialização do capital" têm a cara do revisionismo instaurado por Eduard Bernstein e Karl Kautski, predicado mundo afora com letras garrafais pelos social-democratas e pelos renegados do marxismo-leninismo. De minha parte, não afeito a oximoros e eufemismo continuo considerando que o mundo vive o capitalismo (imperialismo) em sua etapa terminal, muito embora não se possa afirmar com precisão o momento exato do seu último suspiro.

\section{Acerca do imperialismo}

A densidade histórica da categoria imperialismo reclama a feitura de uma análise acurada das modernas modificações mundiais empreendidas contemporaneamente pelo capitalismo. Basta observar que o desenvolvimento deste modo de produção produziu alterações no início do século XXI, antecipadas por Lenin no alvorecer do século XX, em número de cinco, são elas: (1) domínio da vida econômica pelos monopólios, (2) criação do capital financeiro especulativo e da oligarquia financeira, (3) predomínio da exportação de capitais, em detrimento da exportação de mercadorias, (4) fusão de grandes empresas, 
(5) partilha do mundo em áreas extrativistas entre as sete maiores e mais poderosas potências capitalista, sob comando norte-americano.

Todas essas características, mutatis mutandis, são consubstanciadas hoje pela ideologia neoliberal, proclamada como apoteose das formulações teóricas do capitalismo, a qual aponta à possibilidade de elevar a condição de vida do proletariado e dos trabalhadores assalariados para patamares invejáveis ao mais rigoroso teórico marxista e aos próprios Marx, Engels e Lenin.

O imperialismo sob o ponto de vista político e econômico da tradição marxista, fase superior do capitalismo, tem seus passos iniciais cravados no crepúsculo do século XIX e primórdios do século XX, desenvolvendo-se de forma absoluta e incontida no alvorecer do século XXI. É inquestionável que o capitalismo alcançou sua forma superior de desenvolvimento e agora já não exporta apenas mercadorias, mas também capital e mais mercadorias. Reprimido em suas próprias fronteiras, para sobreviver e exercitar-se de forma imperial, o capitalismo precisa se expandir e para isto é preciso quebrar seu casulo nacional, lutar e abocanhar outras regiões e países do globo terrestre. O imperialismo é a marca decisiva e absoluta que diferencia os séculos XX e XXI dos demais séculos antecedentes.

Numa conferência sobre a relação entre o proletariado e a guerra, Lenin observa que;

O último período do século XIX e o começo do século XX se distinguem pela política imperialista. (...) O imperialismo é um estado do capitalismo em que este, depois de haver realizado todo o que podia realizar, dá uma virada à decadência. É uma época especial não na consciência dos socialistas, senão nas relações efetivas. ${ }^{\text {xii }}$

Movimentava-se sorrateira e implacável a ideologia e as práticas nacionalistas que as burguesias nacionais tratavam de transplantar a outras épocas distintas por completo, para ratificar a expansão dos impérios. Nos séculos XIX, XX e XXI o movimento socialdemocrata e socialista pequeno burguês, irremediavelmente oportunista e a reboque da burguesia, abandonou o ponto de vista da democracia operária, passando a adotar o ponto de vista da velha democracia burguesa.

Os séculos XIX e XX representam a época do triunfo gradual da burguesia sobre as caducas instituições feudais, monárquicas e absolutistas; época dos movimentos nacionalistas, movimentos democráticos burgueses que avançavam para assumir o controle total das sociedades ocidentais, a exemplo do que ocorria na Rússia que, ao mesmo tempo, evidenciava a transição da burguesia progressista ao caminho do capital financeiro ultrareacionário ou banditismo das finanças.

Diante disto, Lenin atribuiu a si mesmo e aos seus pares a missão de desmascarar o oportunismo menchevique e patrioteiro e criticar duramente o "pântano" que fazia a defesa verbal do internacionalismo, enquanto na prática montava uma aliança com os inimigos da classe operária que corria por dentro do movimento operário internacional e ajudava a preparar a época do imperialismo e as comoções imperialistas dele derivadas.

A situação histórica objetiva onde medrava a adolescência do imperialismo era nada mais nada menos que a

luta do capital financeiro ascendente pela liberação nacional contra o feudalismo, cedeu o lugar à luta contra as forças novas do capital financeiro ultra-recionário, decrépito e caduco, em marcha descendente 
até a decadência. Os limites nacionais que, num primeiro momento, eram a alavanca do desenvolvimento das forças produtivas da humanidade que se libertava do feudalismo, se converteram agora (...) em obstáculo ao sucessivo desenvolvimento das forças produtivas. De classe avançada em ascensão, a burguesia passou a ser uma classe decadente, interiormente carcomida e reacionária. ${ }^{\text {xiii }}$

Sobre as afirmações de Lenin a respeito da burguesia, de 1789 a 1917, nos dias hoje, não são necessários comentários extras, comprovadas são nos mais diversos boletins e noticiários diários, diuturnos que compõem a programação burlesca, nauseabunda, da mídia televisiva burguesa. Assistindo-os é possível ver claramente, sem subterfúgios, a burguesia brasileira como classe decadente, interiormente carcomida e geneticamente reacionária, proliferando-se em dissolutos bacanais e goliardescos festins, comemorando o lucro do capital sobre a miséria e a ruína do trabalho.

As atuais guerras são feitas como as de antigamente, têm por objetivo fulcral a partilha dos territórios alheios transformados em neocolônias, áreas de extração de matérias primas. Quando os bandidos das finanças internacionais, os ladrões apátridas "sem fronteiras lutam entre si e apresentam os seus interesses como interesses do povo ou da pátria, é uma cínica mentira burguesa". xiv

Ao povo que sofre as conseqüências da guerra, deve-se dizer sempre a verdade, e essa verdade consiste em ser impossível colocar-se a salvo das calamidades produzidas pela guerra (ela própria uma calamidade) sem uma luta ferrenha e duradoura "para derrotar os governos e a burguesia de cada país beligerante". ${ }^{x v} \mathrm{Se}$ as guerras e as revoluções anteriores a 1917 eram realizadas para resolver as questões da transformação democrática burguesa e para derrotar o absolutismo feudal ou a opressão estrangeira, tal decorria das condições objetivas e das condições subjetivas necessárias à realização da revolução socialista e que ainda não estavam postas, não haviam amadurecido.

Contrariando a cínica mentira burguesa e os sofismas segundo os quais nenhum socialista poderia falar, antes de fevereiro de 1917, em utilizar uma revolução para precipitar a demolição do capitalismo, entendemos que muito antes de 1907 e até mesmo antes da primeira guerra imperialista, os socialistas de todos os países beligerantes se reuniram sob a seguinte declaração na Resolução de Stuttgart: "utilizaremos a guerra "para precipitar a demolição do capitalismo",. xvi

Não é possível fugir e nem ocultar a seguinte verdade histórica, em sua etapa imperialista o capitalismo se internacionalizou e moderna e contemporaneamente se caracteriza pela repartição do mundo e domínio de áreas estratégicas,

entre as 'grandes' nações, entre as nações privilegiadas que oprimem todas as demais. As migalhas do botim proporcionado por estes privilégios e por esta opressão vão parar, indubitavelmente, em mãos de certas camadas da pequena burguesia e da aristocracia e burocracia operárias. ${ }^{\text {xii }}$

Se o imperialismo nos séculos XIX e XX representava a subordinação das populações das Nações oprimidas ao capital financeiro e à repartição do mundo entre cinco ou seis grandes potências, contemporaneamente representa a subordinação dos países "pobres" às demandas esfaimadas dos sete países mais "ricos" que participaram de todas as guerras imperialistas do século XX. Esta repartição significa que todos os nababos das grandes potências, o banditismo financeiro e a indústria da guerra de extermínio estão 
interessados na possessão de neocolônias, esferas de influência estratégica, no subjugamento de outras Nações.

O imperialismo, movimentando-se mais claramente desde a primeira grande guerra imperialista (1914-1918), é a fase superior do capitalismo onde o desenvolvimento das forças produtivas e o conseqüente crescimento do capital rebaixa os estreitos limites dos diferentes Estados nacionais. Nota-se ainda hoje, mais que dantes,

a tendência das grandes potências à escravizar outras nações e a conquistar colônias como fontes de matérias primas e mercados para a exportação de capitais. O mundo inteiro formava um organismo econômico único ${ }^{\text {xviii }}$, o mundo inteiro estava repartido entre um punhado de grandes potências . ${ }^{\text {ix }}$

Em 1915, Lenin afirmava o que hoje é por demais conhecido, as consequiências do imperialismo para a classe operária e trabalhadores assalariados: exacerbação da miséria, da desocupação, do aumento do custo de vida, do jugo dos trustes, do militarismo e da reação política contra quem levanta a cabeça de resistência em todos os países. Está tudo controlado. Tudo está sob o controle dos países imperialistas centrais. Talvez, não tudo, à medida que não se consegue agrilhoar as idéias.

O capitalismo, como adverte o "Manifesto do Partido Comunista", aninhou-se no mundo inteiro, internacionalizou-se, assumiu e se exercita sobre o monopólio (estatal ou privado, ou ambos numa parceria pecaminosa), alimento indispensável à sua draconiana caminhada. Neste sentido, "a classe operária não pode alcançar seus objetivos de transcendência histórica universal se não combater do modo enérgico o oportunismo e o social-chovinismo declarados, assim como o chamado centro". ${ }^{\mathrm{xx}}$

A etapa imperialista do capitalismo inaugura a era das revoluções sociais, todas as condições objetivas da época atual põem na ordem do dia a luta revolucionária do proletariado e dos camponeses pobres, de modo que, cabe aos comunistas, sem renunciar aos mais diversos meios de luta legal, subordinarem-se à tarefa vital e essencial da luta revolucionária: trabalhar para elevar a consciência revolucionária dos operários. Uni-los na luta revolucionária transformando-a em guerra pela expropriação dos expropriadores (os capitalistas) e "pela conquista do poder político pelo proletariado, uma guerra pela realização do socialismo". xxi

$\mathrm{Na}$ primeira conferência socialista internacional, Lenin reporta que os comunistas não deveriam "enganar o povo com a esperança de uma paz próxima duradoura e democrática que exclua a opressão das nações, com a esperança de uma paz sem necessidade da demolição revolucionária dos governos atuais". xxii O fulcro dessa questão radicava e ainda radica de forma mais clara em que cada país central quando predica a paz, o faz impondo condições imperialistas de exploração e opressão sobre os países periféricos, portanto, a paz capitalista é a paz em proveito dos países capitalistas centrais. $\mathrm{E}$ nada é mais danoso aos operários e trabalhadores assalariados das cidades e do campo que a inculcação da "enganosa idéia de que a contradição entre o capitalismo e o socialismo não é profunda; pois não há nada que possa embelezar melhor a escravidão capitalista". xxiii

Não à utopia pequeno-burguesa na qual a liberdade das Nações em geral seria possível sob o capitalismo. Era preciso assumir a grande decisão: "ou a luta revolucionária ou o servilismo lacaiesco ao imperialismo. Não há meio termo. Os inventores ou obtusos da política da 'linha intermédia' causam o maior dano ao proletariado". xxiv

Sobre a revolução contra o imperialismo, sobreleva considerar que Lenin não era favorável a qualquer guerra, a qualquer custo. Ele entendia o imperialismo como a 
opressão crescente e incontida de um pequeno grupo de Nações sobre as demais, de modo que, era necessário reconhecer o direito das nações à autodeterminação pois, como apontava, um povo que oprime a outros povos não pode ser livre. Neste sentido, "um proletariado que aceite a menor violência de 'sua' nação sobre outras nações não pode ser socialista". ${ }^{\mathrm{xx}}$

A chamada paz democrática tão alardeada e a escamotear a utopia da pequena burguesia socialista que não saberia viver sem o capitalismo, Lenin pondera que o verdadeiro programa de ação é o programa marxista por ser historicamente o único a oferecer "às massas uma explicação clara e precisa de todo o ocorrido, que lhes aclara o que é o imperialismo e como se deve lutar contra ele". xxv

Esta fala está relacionada com as atuais condições das relações entre as mais diversas nações do planeta: "O capital se fez internacional e monopolista. O mundo está repartido entre um punhado de grandes potências (da Europa: Inglaterra, França, Rússia e Alemanha) que prosperam saqueando as outras nações". ${ }^{x v v}$

$\mathrm{Na}$ época atual onde, por um lado, registra-se o mais alto desenvolvimento científico e tecnológico do capitalismo mundial, do outro lado, este desenvolvimento só foi possível em virtude da ação de rapina exercida sobre bilhões de habitantes da Terra, por minorias parasitárias internacionais. Sobre isto, Lenin faz a seguinte contestação:

No capitalismo é impossível qualquer outra [forma] de organização. Renunciar às colônias, às 'esferas de influência', à exportação de capitais? Pensar nisto significa descer ao nível de um padreco que predica cada domingo aos ricos a grandeza do cristianismo e os aconselha presentear os pobres (...). [Portanto], a guerra não está em contradição com os fundamentos da propriedade privada, senão que é o desenvolvimento direto e inevitável de tais fundamentos. No capitalismo é impossível um processo uniforme de desenvolvimento econômico das distintas economias e dos distintos Estados. O capitalismo, para restabelecer de quando em quando o equilíbrio alterado, não há outro meio possível que as crises na indústria e as guerras na política. (...) A desigualdade do desenvolvimento econômico e político é uma lei absoluta do capitalismo. ${ }^{\text {xviii }}$

Diante deste quadro hediondo, Lenin considerava impossível que o capitalismo e as classes sociais fossem suprimidas sem uma ditadura do proletariado. Assim sendo,

os Estados Unidos do mundo (e não da Europa) constituem a forma estatal de unificação e liberdade das nações, forma que nos relacionamos com o socialismo, enquanto que a vitória definitiva do comunismo não traga a desaparição definitiva de todo Estado, incluindo o Estado democrático. Sem embargo, como consigna independente, a dos Estados Unidos do mundo com pouca probabilidade seria justa, em primeiro lugar, porque se funde com o socialismo e, em segundo lugar, porque poderia conduzir à falsa idéia da impossibilidade da vitória do socialismo em um só país e uma interpretação errônea das relações deste país com os demais. ${ }^{\text {xxix }}$

Tem-se aqui o seguinte problema, se é fato que o desenvolvimento econômico e social das Nações é uma lei absoluta do capitalismo, então a livre união de todas as Nações 
e a sua constituição equânime é impossível sem a luta feroz e violenta do movimento operário internacional contra os Estados capitalistas.

Mas há uma questão de elucidante surpresa, a possibilidade de realização do socialismo num só país é de Lenin, tal como ele grafou no texto A consigna dos Estados Unidos da Europa. Essa propositura não é de Stalin como afirmam ainda hoje, aqui e alhures, e à exaustão, os trotskistas. Foi Lenin quem deduziu ser "possível que o socialismo triunfe primeiramente em poucos países, ou inclusive em um só país capitalista" ${ }^{x x x}$ No informe do Conselho de Comissários do Povo em dezembro de 1919, Lenin repete o que sempre dizia, mesmo antes de Outubro e durante a Revolução de Outubro, os comunistas bolcheviques russos se consideravam apenas como um dos destacamentos do exército internacional do proletariado, na verdade, o destacamento que havia assumido a vanguarda dos demais, não em virtude de seu desenvolvimento e de sua preparação política e militar, mas como decorrência das condições objetivas e subjetivas excepcionais da Rússia. Eles não deveriam esquecer, jamais, que a vitória definitiva da revolução socialista russa seria uma consequiência da vitória do proletariado de vários países avançados. ${ }^{\mathrm{xxxi}}$

Uma característica marcante define o período principiado no início do século XX: o imperialismo é a etapa monopolista do capitalismo e nela o seu desenvolvimento histórico "se transformou em um sistema universal de subjugamento colonial e de estrangulamento financeiro da imensa maioria da população do planeta por um punhado de países adiantados". xxxii

O capitalismo ao chegar a um determinado estágio do seu desenvolvimento, ou seja, a concentração de capital por si mesma conduz direta e inevitavelmente ao monopólio, resultando para algumas poucas empresas gigantescas a facilidade de construírem um acordo hediondo e macabro entre si, "a transformação da concorrência em monopólio é um dos fenômenos mais importantes - para não dizer o mais importante - da economia capitalista dos últimos tempos". xxxiii

Os intelectuais burgueses manipulando a ciência oficial, ciência da parcimônia (a economia e seu instrumental estatístico), intentam

aniquilar mediante uma conspiração do silêncio a obra de Marx, o qual havia demonstrado, com uma análise teórica e histórica do capitalismo, que a livre concorrência origina a concentração de produção, e que dita concentração, em um certo grau de seu desenvolvimento, conduz ao monopólio. ${ }^{\text {xxiv }}$

Mais incrível ainda é compreender e aceitar que esses mesmos intelectuais, diante do quadro caótico internacional onde todas as evidências apontadas por Marx são confirmadas, permanecem proclamando em coro e uníssono que o marxismo foi refutado. $\mathrm{Na}$ etapa em questão do desenvolvimento capitalista, os cartéis tornam-se um dos fundamentos de toda a vida econômica, o capitalismo transforma-se em imperialismo, com outras palavras, o imperialismo surge como desenvolvimento e continuação direta das propriedades fundamentais do capitalismo.

O capitalismo representa, ainda hoje, o desigual desenvolvimento entre as Nações e a subalimentação das massas. Estas são as duas condições ou premissas básicas inevitáveis deste modo de produção. Enquanto o capitalismo permanecer como tal, o excedente de capital, uma decorrência da mais absurda extorsão exercida sobre o trabalho alheio, não será destinado à elevação do nível de vida dos operários e trabalhadores assalariados, 
mesmo porque se tal ocorresse significaria, inevitavelmente, a diminuição do lucro a razão de ser da burguesia.

Acresce que o paradoxal aumento de lucro tem sido compensado em alguns países centrais por intermédio da exportação de capitais para a periferia, numa verdadeira sangria econômica bem delineada por Eduardo Galeno no texto "As Veias Abertas da América Latina".

A tese de Marx e Engels no Manifesto do Partido Comunista foi adormecida na consciência dos intelectuais do proletariado, em virtude de ter sub-dimensionado o potencial de recomposição do capitalismo e superestimado as potencialidades metabólicas e imunológicas do infante socialismo, um organismo novo récem-nato a caminhar desde cedo numa rota adversa e de previsível colisão, em curto prazo, com o velho organismo decrépito, o capitalismo.

O erro crasso da esquerda reformista na ex-União das Repúblicas Socialistas Soviéticas, após o XX Congresso do Partido Comunista da URSS, e da esquerda seguidista no Brasil, foi considerar o processo em curso de construção naquele país, no Leste da Europa e em outros locais do Planeta, Cuba, China, Coréia do Norte como inevitável e irreversível. Para essa esquerda acrítica o capitalismo estava com os seus dias contados, essa análise, não leninista, sacrificou a crítica elaborada por Marx e Engels sobre a realidade capitalista ao dogmatismo, às concepções novidadeiras, tornando-a presa fácil de uma concepção de mundo a argüir o capitalismo por fim último da humanidade.

As formas de propriedade e de exploração capitalistas, se modificaram [se modificam!] consideravelmente, influenciadas pelo desenvolvimento das forças produtivas e, seguramente, pelo que se convencionou chamar de revolução científico-tecnológica. Com isto, o imperialismo pode ser representado qualitativamente como uma nova formação sócio-econômica. Não há dúvidas, o imperialismo é o capitalismo mais parasitário ainda, faminto, moribundo e putrefeito. Sobre ele a teoria científica do desenvolvimento do capitalismo re-elaborada por Lenin estabelece uma classificação completa e rigorosa desse aspecto do desenvolvimento social burguês a partir de teses pontuais:

A concentração da produção e os monopólios.

Isso implica no "colossal incremento da indústria e do processo rapidíssimo de concentração da produção em empresas cada vez maiores". ${ }^{x x x v}$ Nascem assim os monopólios que exercem um papel decisivo na vida econômica dos países capitalistas. A transformação do capitalismo concorrencial em monopolista "constitui um dos fenômenos mais importantes (...) da economia do capitalismo dos últimos tempos".xxxvi

O domínio dos monopólios capitalistas sobre a vida econômica de determinadas sociedades tem por corolário sua onipotência na esfera política. Observa-se o suborno exercido sob o aparelho de Estado do qual se servem os capitalistas para enriquecerem cada vez mais. Lei inexorável do capitalismo monopolista, a concentração de riquezas continua crescendo sem cessar.

Cumpre assinalar que os intelectuais burgueses, mormente os economistas, tentam deixar a obra de Marx à crítica roedora dos ratos, à medida que nela está demonstrado corretamente, pela análise teórico-histórica rigorosa e precisa do capitalismo, que a 'livre' competição origina a concentração da produção e que essa concentração, em determinado momento do seu desenvolvimento, conduz ao monopólio.

Lenin resume da seguinte maneira o desenvolvimento do imperialismo:

Primeiro, entre 1860 a 1870 , ocorreu o ponto culminante de desenvolvimento do capitalismo concorrencial ou de livre competição; 
segundo, após 1873 houve um largo período de implantação e desenvolvimento dos cartéis; e, terceiro, no auge do final do século XIX e início do século XX, exatamente com a crise de 1900 a 1903, os cartéis se convertem numa das bases de toda a vida econômica. O capitalismo se transforma, então, em imperialismo. ${ }^{\text {xxvii }}$

Os bancos e o seu novo papel.

Lenin chama a atenção para a fusão do capital industrial com o capital bancário e, conseqüentemente, a criação, baseada nessa fusão, da oligarquia financeira.

$\mathrm{Na}$ verdade, à medida que vão aumentando as operações bancárias e que se concentram num número reduzido de estabelecimentos, os bancos se convertem, de modestos intermediários que eram antes, em monopolistas onipotentes que dispõem de quase todo o capital monetário de todos os capitalistas e pequenos patrões, assim como da maior parte dos meios de produção e das fontes de matérias primas de um ou de muitos países. ${ }^{\text {xxviii }}$

Todo Banco é uma bolsa. Com este aforismo moderno, Lenin evidenciou que tanto mais preciso quanto maior é o banco, maiores são os êxitos da concentração dos negócios bancários.

O capital financeiro e a oligarquia financeira

Citando Hilferding, Lenin reporta que o capital financeiro é o capital que se encontra à disposição dos bancos e que os industriais utilizam sem perceber que cedo ou tarde serão submetidos aos ditames bancários.

No entanto, de acordo com seus comentários,

esta definição não é completa porque não indica um dos aspectos mas importantes: o aumento da concentração da produção e do capital em grau tão elevado que conduz, e tem conduzido, ao monopólio. (...) Concentração da produção; monopólios que derivam da mesma; fusão ou união de bancos com a indústria: tal é a história da aparição do capital financeiro e o que dito conceito encerra. ${ }^{\text {xxix }}$

A parte leonina dessa fusão se chama capital especulativo ou volátil, dizem os economistas burgueses, concentrado em poucas mãos obtém um lucro descomunal que aumenta sem cessar com o beneplácito do Estado burguês, consolidando a dominação da oligarquia financeira e impondo a toda a sociedade um tributo perverso em proveito dos especuladores. No Brasil, é possível dizer, quatro grandes bancos gozam do privilégio do "monopólio absoluto" do capital especulativo. A maior lucratividade da oligarquia financeira, como se sabe, ocorre durante os períodos de recessão, na aquisição de médias e pequenas empresas arruinadas adquiridas por preços baixíssimos, numa operação chamada de 'saneamento', 'reorganização' ou reordenação da economia.

Utilizando algumas das teses de Hilferding, Lenin escreve que o saneamento e a reorganização da economia capitalista "têm uma dupla importância para os bancos: primeiro como operação lucrativa, e segundo como ocasião propícia para colocar sob sua dependência essas sociedades necessitadas". ${ }^{\mathrm{x}}$

A exportação de capitais

Diferentemente da exportação de mercadorias, essa nova forma de exportação adquire uma importância extraordinária e caracteriza o capitalismo moderno, no qual 
impera o monopólio. Uma das ponderações postas na obra leninista parece falar sobre a atual realidade dos países da periferia do capitalismo central, à medida que

Naturalmente, se o capitalismo houvesse desenvolvido a agricultura, que hoje em dia em todas as partes está atrasada em comparação com a indústria; se houvesse elevado o nível de vida das massas da população, o qual continua sendo, apesar do vertiginoso progresso da técnica, de subalimentação e miséria, não haveria motivo para falar de um excedente de capital. ${ }^{\text {xli }}$

Neste sentido, como nada disto foi estabelecido, esse tipo de exportação está determinado devido ao fato no qual os países periféricos foram incorporados à circulação do capitalismo mundial e obedecem ainda ao fato que nos países centrais "o capitalismo 'amadureceu excessivamente' e o capital necessita, devido ao desenvolvimento insuficiente da agricultura e a miséria das massas, de campo para a sua inversão lucrativa" (LENIN, 1983, t. 27, p. 377).

A partilha do mundo entre as grandes potências capitalistas

Marx afirmava que o capitalismo para se tornar o modo de produção hegemônico com certeza caminhava para instalar-se no mundo inteiro. Seguindo esta assertiva é possível ver que os grupos monopolistas partilham entre si, primeiramente, o mercado interno, apoderando-se quase que totalmente da produção interna. Porém, sob o capitalismo há uma inevitável e histórica relação entre o mercado interno e o externo. Na verdade, "faz muito tempo que o capitalismo criou um mercado mundial". xlii

O mercado capitalista mundial possibilitou a constituição de cartéis internacionais. Esse fenômeno produziu um novo grau de concentração mundial do capital e da produção, um grau incomparavelmente mais elevado que os anteriores. O traço mais característico deste período, em seu momento contemporâneo, é a partilha da América Latina e da África entre as grandes potências, notadamente, USA, Japão, França, Alemanha e Inglaterra (se incluirmos a Rússia, são as mesmas potências denunciadas por Lenin em 1916) que procuram reunir em suas mãos todas as fontes de matéria prima (minérios, petróleo etc.) localizadas nas "neocolônias", envidando todos os esforços possíveis e ao seu dispor para subtrair à periferia e aos adversários centrais toda a possibilidade de concorrência. A posse absoluta ou quase absoluta das colônias é o mecanismo que, de maneira plena, garante o sucesso do monopólio imperialista.

Segundo Lenin,

a particularidade fundamental do capitalismo moderno consiste na dominação das associações monopolistas dos grandes patrões. (...) a possessão de colônias é o único que garantirá de uma maneira completa o êxito do monopólio contras as contingências da luta com o adversário, (...) quanto mais desenvolvido está o capitalismo, quanto mais sensível se torna a insuficiência de matérias-primas, quanto mais árdua é a competição e a busca das fontes de matérias primas em todo o mundo, tanto mais encarniçada é a luta pela aquisição de colônias. ${ }^{\text {xliii }}$

Para a oligarquia financeira internacional não são apenas as empresas estatais, supostamente deficitárias e seu balaio de matérias-primas já conhecidas e da máxima importância, mas também as possíveis fontes de riqueza, posto que, nos nossos dias, o avanço incontido da tecnologia pode propiciar a construção de mecanismos alternativos 
para, por exemplo, tornar aproveitáveis amanhã as terras improdutivas de ontem, se forem investidos grandes somas de capital.

É historicamente correto utilizar o vaticínio de Lenin a caracterizar o imperialismo como a mudança de rumo da democracia para a reação política. Mudança de rumo que encontra sua maior expressão: (a) no aumento dos investimentos na área militar, os aparelhos repressivos do Estado (forças armadas, polícias, sistemas judiciário e prisional, órgãos de vigilância e controle social, etc.), inconseqüente redução na área educacional, objetivamente, no terceiro grau ou ensino universitário, área de saúde e dantesca redução do investimento no sistema energético; (b) na violação dos direitos sociais e individuais firmados de forma pétrea na Carta Constitucional; (c) e na quebra da legalidade - uso do arbítrio e emprego dos meios repressivos contra a população pobre e/ou remediada (professores, funcionários públicos, sem-terra, sem-teto, etc.) e a classe operária.

Os imperialistas não abandonam jamais os métodos convencionais da democracia burguesa, não, mesmo porque eles apenas recorrem ao terrorismo ideológico e prático (ameaça de espancamento de sindicalistas, professores, trabalhadores rurais sem terra, os sem teto etc.) quando sua dominação é posta em cheque. De um modo geral, preferem governar sob o manto do parlamento, do sufrágio universal, ancorados noutras instituições ‘democráticas' que ocultam o caráter cesarista dos governos burgueses.

Após ter sido julgado em suas características e contradições principais, o imperialismo é a luta da burguesia agonizante, decrépita e podre, pela repartição do mundo e o subjugamento das nações pobres, emergentes ou ricas em petróleo.

O que é lógico no capital?

Diante da lógica binária do capital e frente ao irrefutável quotidiano onde os princípios foram deixados à margem da estrada como entulhos ideológicos da história, aquele (intelectual ou professor) que não compreende: em primeiro lugar, que o ambiente social no qual vive e elabora seus "projetos" é um ambiente burguês e que, por isto mesmo, todas as melhorias realizadas no seu âmbito significam progresso e melhoria da situação da minoria, proletarização e empobrecimento da maioria; em segundo lugar, que o Estado ao qual dirige seus projetos de políticas públicas é um Estado da burguesia para apoiar e salvaguardar os opressores e aplastar os oprimidos, é um ingênuo, um ignorante ou um oportunista; e, em terceiro lugar, que o tal "governo popular e democrático" não é antípoda do capitalismo, mas sua continuação direta, mais próxima e imediata, seu desenvolvimento e seu fortalecimento. É porque ou é um ingênuo, um ignorante ou um oportunista.

Certamente, aquele intelectual ou professor não consegue advogar como necessário o romper definitivo com as idéias e teorias pedagógicas pequeno-burguesas. Não admite ser esse o principal ensinamento tirado do dia a dia da cidade do capital e nem apontá-lo como conteúdo da educação para os trabalhadores (operários e camponeses pobres). Não consegue compreender que enquanto a economia política aumenta em proporções incomensuráveis o oceano de miséria, de desemprego forçado, de extenuação pela fome; porta-voz da burguesia apela com a consciência tranqüila às profecias mais caducas e levianas.

Neste quadro, um outro sistema educacional baseado no tripé - educação intelectual, educação para o trabalho e educação física - deveria apresentar objetivamente a luta popular como produto de determinado sistema de relações de produção, apontar a necessidade desta luta, seu conteúdo, o curso e as condições do seu desenvolvimento. Neste processo não se deve assumir a luta perdendo de vista o caráter geral do seu real objetivo: "destruição completa e definitiva de toda exploração e de toda opressão venha de onde vier, esteja onde estiver". xliv 
Como o operário e o camponês pobre poderão entender a urgência da transformação da relação de dominação e extorsão quando eles mesmos são educados pela realidade que os domina e extorque?

Como poderão entender que o capitalismo é freio e obstáculo reacionário do desenvolvimento humano e que foi "convertido em poder omnímodo de um punhado de milionários e multimilionários que empurram os povos ao matadouro para resolver o problema de que à grupos de piratas, o alemão ou o anglo-francês, devem ir parar o botim imperialista, o poder sobre as colônias, as "esferas de influência" financeiras etc."? ?lv $^{\mathrm{xl}}$

Como poderão compreender que a "democracia burguesa não é mais que a liberdade para os capitalistas, liberdade de subornar a opinião pública e esmagá-la com a onipotência do dinheiro"? ${ }^{x l v i}$

Como poderão compreender que a transformação da sociedade, ou seja, a transição do capitalismo para o socialismo só é possível mediante a ditadura da classe operária e do campesinato?

Sobre a ditadura do proletariado Lenin reporta que as categorias democracia e ditadura, quando universalizadas e colocadas acima da luta de classe contra classe ou à margem das classes litigantes, é apenas "um escárnio direto sobre a teoria principal do socialismo, quer dizer, da teoria da luta de classes, reconhecida de palavra e esquecida na prática pelos socialistas que passaram para o lado da burguesia". xlvi

E mais ainda, diz ele. quando um marxista abordar esta questão deveria fazê-lo explicando:

O caráter de classe da sociedade burguesa, da democracia burguesa, do parlamentarismo burguês e expressar a idéia formulada com a máxima precisão científica por Marx e Engels quando disseram que a república burguesa, mesmo a mais democrática, não é mais que uma máquina para a opressão da classe operária pela burguesia, da massa de trabalhadores por um punhado de capitalistas. xlviii

Acuados em sua relativa ignorância, os intelectuais da educação não vêm que o desenvolvimento da atual sociedade segue duas vias:

A via de manutenção da burguesia industrial, fundiária e financeira, criação de um campesinato forte com "espírito burguês" e uma aristocracia operária a trair sua própria classe, e a via da abolição da propriedade privada em geral e geração de camponeses e operários livres, mediante a troca radical da base histórica da sociedade em transformação.

O diversionismo ideológico predicado pelos mais diversos partidos da esquerda revisionista e fisiológicos tem conduzido os trabalhadores, operários e camponeses pobres a assumir posturas políticas anacrônicas encobertas com concepções neoliberais tingidas de progressista e até mesmo de marxista. ${ }^{\text {xlix }}$

Encimados no conceito de hegemonia de Gramsci, os intelectuais da educação e os professores têm no interior da escola um duplo papel: ou forjar "nas massas o consenso em relação a visão de mundo da classe dominante e dirigente e adequando o comportamento dos subalternos às necessidades do grupo no poder", uma espécie de adequatio intellectus et rei da antiguidade clássica; ou "disputar o poder, criando as condições objetivas e subjetivas para romper com a hegemonia em vigor e, assim, possibilitar a construção de uma nova civilização".

Há nessa formulação algumas dificuldades. Em primeiro lugar, parece estar esquecido que os professores e professoras na sua quase totalidade não estão propostos à disputar a hegemonia que bem não sabem de quem: do prefeito, do governador, do 
presidente ou da classe social dominante de quem os políticos são prepostos. Esses professores não misturam educação com política, no que fazem muito mal. Em segundo lugar, acredita-se que o rompimento da hegemonia da classe dominante dar-se-á de forma pacífica e ordeira sob o olhar compreensivo e complacente da burguesia. Em terceiro lugar, quem, de verdade, tocará o processo de disputa e quebra da hegemonia do capital sobre o trabalho: um grupo ou uma classe? Se for um grupo é blanquismo, se for uma a classe explorada será uma revolução, de todo modo estamos diante de um impasse: reforma ou revolução.

O idealismo contagiante prevalente na educação admite a possibilidade de um novo processo educativo para "reformular a consciência das classes subalternas e construir novas relações sociais, o que naturalmente depende de uma 'reforma filosófica total", ou seja, a troca da filosofia dominante pelo marxismo, identificado "como sendo a filosofia das classes subalternas de seu tempo". ${ }^{\text {li }}$

Uma nova contradição desponta: como mudar o paradigma filosófico, quando o marxismo foi alijado dos bancos es colares universitários e no seu lugar foram colocados as mais reacionárias correntes filosóficas e políticas, por exemplo, o positivismo no seu largo espectro?

Como apontava Lenin,

só os bobos crêem que o proletariado deve primeiro conquistar a maioria nas votações realizadas sob o jugo da burguesia, sob o jugo da escravidão assalariada, e que só depois deve conquistar o poder. Isto é o colmo da estultícia ou da hipocrisia, isto é substituir a luta de classes e a revolução por votações sob o velho regime, sob o velho poder. ${ }^{\text {lii }}$

As interpretações idealistas da natureza, da história e, naturalmente, da educação

Propostas pelos filósofos, invocam princípios como o espírito, a razão, a consciência, a idéia... E porque, na prática, esses princípios resultam sempre não na revolução, mas na educação (ou até na edificação) das massas, cuja causa os filósofos se propõem generosamente a assumir. No tempo de Platão, eles pretendiam aconselhar os príncipes em nome da Cidade ideal. Em nossa época democrática, eles pretendem educar os cidadãos (ou "educar os educadores" dos cidadãos: os juízes, os médicos, os professores, instalando-se, pelo menos moralmente, no alto do edifício universitário) em nome da razão e da ética. liii

Permanece no âmbito da educação (escola) e do trabalho (sindicatos em geral) a luta de classes predominantemente ideológica, de um lado, os que advogam a manutenção da ideologia hegemônica da classe dominante (o neoliberalismo) e, do outro, os que resistem à imposição e buscam construir uma nova hegemonia, proletária e comunista. ${ }^{\text {liv }}$

É preciso pensar a educação e o mundo do trabalho não apenas como instrumentos de reprodução das relações de produção capitalista, mas como importantes locais de luta de classes dando-se no plano das idéias, da ideologia. Entretanto, é preciso deixar bem claro não ser possível superar plenamente os problemas e as limitações da educação e do trabalho alienado, determinadas pela sociedade capitalista, sem a efetiva superação dessa sociedade. Como adverte Duarte, "não é possível superar, do ponto de vista teórico, de forma plena, as pedagogias de cunho liberal burguês, sem a superação da realidade social contraditória da qual nasceram essas pedagogias". lv 
Acorde com Duarte, essas pedagogias desempenham o papel de "cavalo de Tróia" trazido para dentro da escola e dos sindicatos de trabalhadores, e "para dentro das pesquisas sobre a educação". "li O conteúdo pedagógico do "cavalo de Tróia" consubstancia a apologia das teorias que reafirmam o capitalista em sua etapa imperialista como fim último da humanidade, afirmando implicitamente que:

Em uma Nação livre na qual não se permite a escravidão, a riqueza mais segura consiste numa multidão de pobres laboriosos. Para fazer feliz a sociedade e manter contentes as pessoas, ainda que nas circunstâncias mais humildes, é indispensável que o maior número delas seja ao mesmo tempo de pobres e totalmente ignorantes. .vii

Chamo a atenção para o seguinte postulado de Saviani:

O desenvolvimento da educação e, especificamente, da escola pública, entra em contradição com as exigências inerentes à sociedade de classes de tipo capitalista. Esta, ao mesmo tempo em que exige a universalização da forma escolar de educação, não a pode realizar plenamente, porque isso implicaria a sua própria superação. ${ }^{\text {lviii }}$

Nesta perspectiva, a educação encimada no acesso de todos, em igualdade de condições e com o mesmo padrão de qualidade do ensino, possibilitaria a apropriação do saber pela totalidade dos filhos e filhas da classe operária e dos camponeses pobres, ou seja, o trabalho se apropria do saber do capital com o qual poderá cessar a sua condição subalterna. Todavia, essa pretensão se choca com a própria estrutura da cidade do capital, fundada exatamente na apropriação privada dos meios de produção material e intelectual: donos do capital, donos do conhecimento. É preciso entender que o saber, o conhecimento ou os conteúdos clássicos da educação oficial, como força produtiva independente do trabalhador se define como propriedade privada do capitalista.

Como adverte Saviani:

O trabalhador, não sendo proprietário de meios de produção, mas apenas de sua força de trabalho não pode, portanto, se apropriar do saber. Assim, a escola pública, concebida como instituição de instrução popular destinada, portanto, a garantir a todos o acesso ao saber, entra em contradição com a sociedade capitalista. ${ }^{\text {lix }}$

Na sua radicalidade o desafio posto pela cidade do capital à educação transformada "só poderá ser enfrentado em sentido próprio, isto é, radicalmente, com a superação dessa forma de sociedade". ${ }^{\mathrm{x}}$ Nesta empreitada, superação da sociedade capitalista, o método de estudo e trabalho que deve ser adotado em sala de aula, válido para hoje, encerra quatro exigências:

Primeiro, comprovar e demonstrar os dogmas com os quais os reformistas apascentam a chama revolucionária do proletariado. É necessário restabelecer a unidade quebrada entre a teoria e a prática, daí decorrente a famosa frase: sem teoria da prática revolucionária, não há prática revolucionária. Não se trata aqui de uma confraria de ortodoxos que persegue os apóstatas, mas de

Defender a teoria que segundo nossa mais profunda convicção é a verdadeira, contra os ataques infundados e contra os intentos de torná-la pior, não significa, de modo algum, que somos inimigos de toda crítica. Não enfocamos, em absoluto, a teoria de Marx como algo acabado e intangível; estamos convencidos, ao contrário, de que (ele) colocou só as 
pedras angulares da ciência que os socialistas devem impulsionar em todas as direções, para não ser deixado para trás pela vida. ${ }^{1 \times}$

Segundo, comprovar e demonstrar que os horizontes políticos apontados pela social-democracia se distanciam da luta da classe operária. A coerência e a manutenção da unidade teoria e prática é a única condição possível de angariar, conquistar e merecer a confiança do proletariado.

Terceiro, organizar o trabalho sindical e partidário imprimindo-lhe direção revolucionária a fim de educar seus quadros, a juventude e o proletariado, para entender a revolução socialista como a única alavanca ao desmonte da burguesia e edificação da sociedade comunista.

Quarto, exercitar a crítica e a autocrítica, pois a incapacidade de reconhecer os próprios erros e com eles aprender a trilhar novos caminhos e novas metas tem como resultado extremo a criação de uma burocracia despregada da luta pela emancipação intelectual dos trabalhadores urbanos e rurais e rendida aos interesses do capital. Convencido então da necessidade histórica do poder político e econômico passar às mãos do proletariado e dos camponeses pobres, a "esquerda em construção" deverá contagiar o proletariado conclamando-o a apropriar-se do marxismo, o único "armazém" de elementos necessários à sua emancipação intelectual e à sua libertação política e econômica.

A emancipação intelectual é de vital importância para afirmar a certeza de que a classe operária pode e deve tomar o poder e que não manterá o poder se não dispuser de quadros ilustrados e administradores formados capazes de organizar a administração do país. É preciso preparar quadros operários nas escolas de trabalhadores para a tomada do poder. A emancipação intelectual é da máxima importância à compreensão de que, primeiro, a tese da greve geral do proletariado ainda é politicamente consistente e, segundo, que a luta exclusivamente parlamentar é uma ilusão onde o operário não esclarecido permanece escravo dos humores do capital.

É de fundamental importância a educação política dos trabalhadores urbanos e rurais com o objetivo de formar a consciência socialista. Longe de ser um mero esquadrinhar dos clássicos da literatura política e filosófica mundial, o método adotado vai de encontro ao oportunismo e contra toda "vacilação, desorganização e anarquia intelectualista" "xiii ; é preciso desenvolver uma ampla e multifacetada agitação, oral e escrita, direcionada a combater o espírito de conciliação que oculta "a cabeça sob a asa e predica a cessação da luta da maioria contra a minoria". "xii

Estudar, propagandear e organizar é a tríade necessária às tarefas dos educadores revolucionários e comunistas. A sua prática teórica é da magna importância à medida que a teoria deve dar respostas efetivas à prática social, ou seja, a teoria deve responder aos desafios da vida diária do proletariado e camponeses pobres. Para não se transformar em letra morta da história, a teoria deve ser testada pelos dados da experiência enquanto construção histórica.

A educação na cidade do capital é um meio ambíguo de reprodução e transformação possível e de disputa entre o capital social e cultural e o trabalho. Mas não se deve esquecer que a educação depende da economia política. Neste sentido, o desafio da educação escolar brasileira, consiste em contribuir com a formação das novas gerações, tornando-as capazes de decifrar e frear as políticas públicas populistas, assistencialistas, demagógicas, eleitoreiras e, sobretudo, agentes de transformação social para efetivar a educação popular como trincheira do processo indispensável de emancipação intelectual do proletariado e da construção do socialismo. 
A questão da educação escolar e a construção de uma pedagogia socialista (cujo mote é a educação para o trabalho, educação intelectual e educação física) são pertinentes ao atual estágio da sociedade brasileira. É preciso sistematizar e refletir sobre a aplicabilidade de uma pedagogia socialista na escola do capital a partir dos fundamentos da concepção marxista de mundo.

Neste sentido, é possível assumir algumas teses:

Tese 1 - A reforma pedagógica. Nenhuma reforma pedagógica, verdadeiramente popular e democrática, será efetivada antes que a classe interessada no seu concurso assuma o controle dos meios e instrumentos de produção material e intelectual.

Tese 2 - A educação política. Diferente da educação capitalista ela contempla especialmente os interesses da classe operária e dos camponeses pobres. Essa educação é indispensável para que a classe social dominada retire o mando dos meios e instrumentos de produção, do Estado e seus aparelhos ideológicos e repressivos, das mãos da burguesia, assumindo-os para implementar o desmanche do velho sistema, pari passu, com a construção de uma nova sociedade.

Tese 3 - A prática social. O educador comunista deve laborar no controvertido caminho da escola e da Universidade públicas, com cuidado para não ficar condicionado aos estreitos limites impostos pela Nomenklatura acadêmica, nos quais a ordem burguesa põe por objetivo sinecuras e prebendas.

Tese 4 - A transformação estrutural. A escola será sempre um reflexo da transformação estrutural das sociedades. Do escravagismo ao capitalismo ela tem sido uma fiel transmissora do ideário dominante, não sem aceitar a luta de classes em seu ventre. Por isto, entendo a escola como um importante espaço de luta pela solução das contradições materiais e sociais inerentes ao capitalismo. A escola não é apenas uma peça no jogo da reprodução de idéias dominantes de uma época, mas também lócus onde é travada a luta de classes e onde as idéias heréticas circulam perigosamente.

Este parece ser o paradoxo da educação: destinada à reprodução serve, também, à transformação. Diante deste paradoxo irrefutável permanece viva a crítica sobre os intelectuais que teimam em "creditar" à escola a resolução das questões da educação oficial.

Por vezes os apologistas da educação neutra esquecem que um elenco de elementos característicos da educação brasileira é impedido de fazer parte dos currículos escolares em todos os níveis, por exemplo: a relação indissociável entre conhecimento metódico e sistematizado e a prática social política; a realidade concreta como ponto de partida e de chegada do processo educativo e da prática científica; os conteúdos são definidos a partir das necessidades políticas; o trabalho educativo a partir de atividades sistematizadas internamente e da militância organizada; o processo educativo só se concretiza a partir do conhecimento científico e da militância organizada.

O cavalo de Tróia

É imprescindível aos trabalhadores assalariados do campo e das cidades dominar o conhecimento que os dominadores dominam como precondição da ação para fazer cessar a exploração e a extorsão praticada pelo capital sobre o trabalho.

Todavia, o conhecimento contido nos clássicos Aos pobres do campo (Lenin); A mistificação das massas pela propaganda política (Sergei Tchakhotine); A situação da classe trabalhadora na Inglaterra (Engels); Sobre a contradição (Mao Zedong); Sete ensaios de interpretação da realidade peruana (José Carlos Mariátegui); A mãe (Máximo Gorki); Pais e filhos (Ivan Turgueniev); Almas mortas (Nikolai Gogol); A geopolítica da fome (Josué de Castro); Morte a vida Severina (João Cabral de Melo Neto); A verdade sobre Cuba (Wright Mills); Educação e luta de classes (Anibal Ponce). Teoria marxista da 
educação (Bogdan Suchodolski) dentre outros, tem sido sistematicamente negado às novas gerações de estudantes.

Este fato me permite elaborar e esposar mais algumas teses para afirmar a educação oficial como um "cavalo de Tróia":

Primeira - A escola e a Universidade públicas não colaboram para a inversão do domínio sobre o conhecimento científico e filosófico produzido / acumulado ao longo da história.

Segunda - A burguesia permanece com medo da expansão da educação pública e da transmissão do conhecimento filosófico e histórico ao proletariado e aos camponeses pobres, pois a educação escolar e universitária ainda é considerada como perigosa à saúde e a vida do modo capitalista de produção da existência.

Terceira - As ideologias burguesas (a conciliação, a colaboração e o liquidacionismo) são providas ao operário e trabalhadores assalariados em particular e aos oprimidos em geral como antídoto contra a educação sindical socialista e comunista.

Quarta - Os intelectuais da educação acreditam estabelecer arbitrariamente e sponte propria os ideais educativos e o suposto projeto pedagógico da escola. Não compreenderam ou não querem compreender que sua atividade intelectual depende, em última instância, das relações de produção dominantes, ou seja, dependem de decisões políticas das quais não participam.

Quinta - A educação oficial, da pré-escola à universidade continua: livresca e mnemônica, negar a luta de classes, defende e afirma os interesses e os valores republicanos de 1789 cuja máscara caiu com as revoltas de 1848 e com a Comuna de Paris.

Sexta - A educação oficial, da pré-escola à universidade ao produzir, reproduzir, divulgar e inculcar a ideologia burguesa na consciência dos estudantes, condena todas as outras formas de conflitos sociais e ameaças reais à ordem burguesa, afirmando que o desenvolvimento capitalista reduzirá as desigualdades entre as classes e conduzirá todos ao reino da liberdade.

O conjunto das teses precitadas aponta para o entendimento onde as teorias novidadeiras da educação, as pedagogias hegemônicas professadas por professores e intelectuais supostamente vinculados aos trabalhadores são absolutamente reacionárias!

São reacionárias porque velam a luta entre capital e trabalho nas modernas relações sócio-econômicas; expõem as coisas como se elas pudessem favorecer a solução dos problemas com medidas genéricas; praticam a redução do ato de ensinar à pedagogia ou à política, como se fosse impossível conciliá-las; apresentam o Estado acima das classes, e o governo como instrumento de todos, capaz de prestar ajuda séria e honesta à população explorada, extorquida, famélica, descamisada.

São reacionárias porque seus arquitetos não compreendem ou não querem compreender a necessidade da luta de classe contra classe levada ao cabo e ao fim pelos próprios operários e camponeses pobres, sem-terra, à consecução de sua emancipação intelectual e liberdade econômica.

Longe de trilhar uma perspectiva desenvolvimentista da consciência individual, deslocada do social, ego delirante... o pedagogo deve participar do processo de criação e desenvolvimento da consciência revolucionária da classe operária, com a qual procura a emancipação intelectual e a libertação econômica. E mais ainda, o educador militante político compreende a educação, em qualquer situação, não como um fim em si, mas um meio à compreensão sobre a necessidade da transformação da realidade.

A contracorrente: um aviso importante! 
Mas qual será o preço a pagar pela ação de enfrentamento ou pela "guerrilha pedagógica" empreendida contra o Estado, a burguesia e, sobretudo, contra a esquerda batida em retirada e para a direita?

A este respeito, Paulo Freire teceu o seguinte comentário:

Aqueles que desmistificam a tarefa de reprodução estão nadando contra a corrente! Nadar contra a corrente significa correr riscos e correr riscos significa, também, esperar constantemente por uma punição ... os que nadam contra a corrente são os primeiro a ser punidos pela corrente e não podem esperar ganhar como presentes fins de semana em praias tropicais. ${ }^{\text {lxiv }}$

Os que nadam contra a corrente são aqueles que têm como desideratum o sonho de transformação social, por isto sustentam uma posição revolucionária que objetiva a diretividade do ensino e a liberdade ao mesmo tempo.

Ao contrário da educação para a domesticação, necessariamente autoritária e retrógrada, a educação revolucionária ${ }^{1 \mathrm{xv}}$ procura e consegue desvendar a razão de ser dos fenômenos sociais de classe. O pedagogo revolucionário ao entender o falso compromisso dos professores que compõem a nova direita da educação, procura tornar público que o objetivo das escolas e das Universidades é a produção em série de analfabetos formais, força de trabalho barata desempregada e neuróticos consumistas.

De forma lamentável, permanece a crença infundada de que os homens podem criar uma nova sociedade, melhores condições de vida para todos, simplesmente por intermédio da educação. A educação é entendida pela nova direita como a única alavanca capaz de fazer saltar a sociedade capitalista e capaz de incrementar o salto qualitativo em direção a uma sociedade essencialmente diferente daquela em que vivemos.

Não se pode esquecer que a educação apenas quando inserida no processo revolucionário $^{\text {lxvi }}$, consegue satisfazer as esperanças nela depositadas, ela se mostrará capaz de participar no e do processo de edificação de uma sociedade realmente humana. Pautada na pedagogia do falso conflito, digo, do consenso, a educação oficial, embora fale de inclusão social, permanece incapaz de participar na empreitada de transformação da sociedade capitalista.

Em face do quadro caótico imposto aos operários, trabalhadores assalariados, funcionários públicos [exceção feita aos apaniguados do governo federal] e aos sem-terra, é preciso criar uma oposição para valer ao mundo burguês ${ }^{\text {lxvii }}$ imperialista cada vez mais excludente, é preciso assumir corajosamente a posição de colaborador do nascimento do mundo novo que está maturando no interior do capitalismo deliqüescente.

O desenrolar da trajetória dos intelectuais da educação, há pelo menos quinze anos, demonstra que eles tratam o fenômeno educativo de forma isolada da economia política de determinada sociedade, como se a educação oficial fosse um a priori indeterminado movendo-se de mote próprio. É como se a educação antecedesse em sua forma e essência à constituição dos educandos.

Os progressistas da educação predicando a covardia diante da vida assumem o messianismo pedagógico e o reformismo diluído na ideologia burguesa, utilizando um insólito charlatanismo. Além de acreditar em flores vencendo canhões, praticam a deformação da concepção de mundo e da corrente de pensamento que preconiza a necessidade histórica do enfrentamento com a classe dominante para que possamos construir uma reforma verdadeiramente pedagógica. 
O "Penso, logo sou!" (Cogito, ergo sum!) tem servido de mote às condutas progressistas: a força do argumento [fracos argumentos] ao argumento da força [o determinante histórico de todas as grandes nações deste Planeta e mantenedor do reinado da burguesia: o capitalismo]. Destarte, à ação revolucionária ou à prática insurrecional total a teoria como real motor das transformações sociais. Paradoxalmente dizem: contra argumentos não há fatos! Progressistas ou reacionários?

Depurando-se do alpinismo social e da "marxologia" oficial etc., os professores revolucionários são cada dia em menor número e, naturalmente, sua prática social permanece voltada para a formação de personalidades multifacetadas, homens e mulheres multifacetadas. Homens e mulheres que, munidos de uma teoria orientada à luta social "armada" em busca de uma sociedade sem classes; personalidades educadas no não adquirir, não possuir, não ter, e nem mesmo ser, isto porque, para eles não é a procura de um simples saber ou de um poder efêmero que se desmancha no ar o alvo terminal: parecenos, ao contrário, lutarão pela dissolução de todo saber adquirido e de todo poder estabelecido.

Os professores aferrados a tendência "progressista", eternamente tendência, vazados de boas intenções continuam trabalhando sobre bases abstratas. Sua fundamentação se sustenta no "objeto" idealizado, pensado ou imaginado, nunca concreto e historicamente dado. Simulacros, abstrações. Com outras palavras, seus pressupostos não são os homens concretos produzindo em sociedade, mas "homens" sem vontade, sem ideologia, sem necessidades, sem cor e sem alma, enfim, "homens" de nada. Nada de homens.

O humanismo progressista ou a preocupação com a educação enquanto práxis [sem poièsis] de "intervenção social", confundida com prática pura e simples, não consegue dar conta das causas da desumanização visível da maioria da população trabalhadora, nesta sociedade de pilantras e apostatas. Seu método de ação é a mediação ou a conciliação e/ou colaboração dos antagônicos, convivência pacífica entre capital e trabalho.

No afã construir o Homo sportivus ou, simplesmente, "humanizar" o Homo sapiens desumanizado pelo trabalho no interior das relações de produção capitalistas, não percebemos que o homem ou é humano ou não o é, e se ele deve ser mais humano, seguramente, é porque é menos humano. Se o Homo deve ser humanizado é porque ele, com certeza, se encontra desumanizado ou está tolhido no e pelo processo histórico aparentemente humanizador.

Humanizar o humano é uma contradictio in terminis ${ }^{\mathrm{lxviii}}$. A humanização de fato necessita do meio previamente humanizado [condições humanas] ou, pelo menos, em franca humanização o que não é o caso da sociedade brasileira, cada vez mais desumana porque sustenta um sistema político econômico antípoda ${ }^{\text {lxix }}$ do processo desumanizador geral e irrestrito. Nesse processo de transformação do Homo sapiens em machina sapiens, vale a pergunta: quais as causas que fazem do Homo sapiens desumanizado uma machina sapiens?

Responder essa questão significa entender o argumento da força como o último reduto, a ultima e extrema ratio de uma classe que, historicamente, precisa libertar-se das próprias grilhetas para libertar a todos nós. A ultima razão, argumentação extrema, é a forma reduzida da expressão ultima ratio regum [última razão dos reis, gravada nos canhões dos exércitos de Luís XIV, por sua própria ordem]. Politicamente essa expressão significa o uso da força quando todos os argumentos lógicos e racionais não são mais suficientes. Diz Hobbes, no Leviatã: "os pactos sem espada são meras palavras".

Para os "progressistas" a possibilidade da mudança social pela prática libertadora da educação, é uma questão crucial à manutenção da sua empregabilidade, mesmo porque, 
eles não sobreviveriam fora das Universidades à medida que nada conhecem dos aspectos técnicos [teoria e prática] que respondem as demandas da sociedade e, seguramente, porque suas parcas teorias em nada contribuem para fazer avançar ou retroceder o mercado capitalista.

Uma prática libertadora da educação não pode prescindir de uma teoria para a libertação, quero dizer, do marxismo, de maneira que sem essa teoria qualquer prática dita "libertadora", "emancipatória" ou "libertária" não consegue ultrapassar os limites do demagógico envergonhado. Sob a ótica progressista da educação, a socialização dos valores dominantes na escola, está direcionada ao pragmatismo servente à sociedade do consumo conspícuo onde os indivíduos de modo anárquico produzem por produzir e a minoria se sobrepõe à maioria.

A hegemonia opta pelo carnaval, futebol e religião como instrumentos do afastamento dos indivíduos, desde criança, dos movimentos políticos revolucionários e como meio de inculcação ideológica a reafirmar o mundo burguês como eterno, imutável. $\mathrm{Na}$ verdade, é preciso re-inquirir: quem educa quem e para que educa?

Sem resposta ou respondida com evasivas ficar-se-á como navio em bom tempo e com vento favorável, mas sem saber a que porto se dirigir. Sobre isto não se pode tergiversar, as crianças e adolescentes são educadas para o conformismo, no máximo para uma falsa ruptura ${ }^{1}$ e não para a desobediência revolucionária que nos levaria à quebra do sistema capitalista. A perspectiva trabalhada no interior da escola, ocultando-se detrás de uma pseudo-dialética, representa a efetiva aceitação e propagação do ordenamento jurídico burguês enquanto reforço necessário e específico à reprodução das relações de produção capitalistas.

Há, contudo, um paradoxo da educação se manifestando no processo educativo que tem de ser considerado: a educação, por ser um processo contraditório ou movido pela contradição, pode tanto propiciar a preparação dos jovens estudantes para a aceitação cabisbaixa do mundo tal como ele é, isto é, para não enxergarem e aceitarem as coisas como elas realmente são, como pode prepará-los para não aceitar o saber e o poder instituídos e, moto contínuo, para "incorporar" o diabo de Goethe objetivando destruir o ordenamento burguês em sua totalidade.

Questões à reflexão:

Como romper com a educação que nos prepara para o individualismo animalesco?

Como anular o "espírito" competitivo [amparado pelo darwinismo social] introjetado desde a mais tenra idade nas crianças?

Como romper com a aceitação passiva das regras marcadas do jogo, ao passo com a aceitação desta sociedade excludente e perversa?

Como fazer um contraponto à apologia da mediação que, numa alusão a uma certa intervenção social, claramente ratifica as trilhas e partilhas da barbárie capitalista?

Se o ato de mediar significa dividir ao meio ou estar ao meio, intervir como árbitro ou mediador ou, simplesmente, ficar entre duas concepções de mundo antagônicas. Então aquele que faz apologia da mediação é o conhecido "em cima do muro" ou que se

\footnotetext{
${ }^{1}$ No mestre Aurélio, este verbete é apresentado como sinonímia de suspensão, corte, interrupção, nada mais profundo ou radical. Apresentada de forma equivocada como sinônimo de revolução, a categoria da ruptura apenas encobre a forma manhosa de ocultação do compromisso político dos "progressistas" com a ordem burguesa. A rigor, a ruptura não pode substituir a revolução enquanto ação coletiva humana direcionada à transformação radical do modo de produção capitalista, grosso modo, de forma violenta, em modo de produção comunista na sua etapa primeira, o socialismo.
} 
apresenta com uma terceira posição ou meio termo, por exemplo, entre o marxismo e o positivismo.

Na cidade do capital a busca pelo terceiro caminho ou pela terceira posição tem sido, ao longo dos últimos 161 anos (tempo de vida do Manifesto do Partido Comunista), uma constante no comportamento da pseudo-esquerda que jamais defendeu o processo revolucionário, sempre viveu em paz com os donos do poder e esqueceu o axioma latino: Tertium non datur! Socialismo ou Barbárie.

Se por acaso eu estiver errado corrijam-me.

\section{Bibliografia}

BALIBAR É. A filosofia de Marx. Rio de Jasneiro: Zahar, 1995.

CASSIM, M. Louis Althusser / referencias para a pesquisa em educação. In: LOMBARDI, J.

C. e SAVIANI, D. (Org.) Marxismo e educação / debates contemporâneos. Campinas: Autores Associados, 2005.

COGGIOLA, Osvaldo A cruzada ética contra o marxismo. Revista Crítica Marxista $\mathrm{n}^{\circ} 14$. São Paulo: Boitempo, 2002.

DUARTE, N. Por que é necessária uma análise crítica marxista do construtivismo? In: LOMBARDI, J. C. e SAVIANI, D.(Org.) Marxismo e educação / debates contemporâneos. Campinas: Autores Associados, 2005.

FREIRE, P. e SHOR, I. Medo e ousadia. São Paulo: Cortez, 1987.

LENIN, V. I. Discurso pronunciado no I congresso nacional de instrução pública. In: Obras Completas em cinqüenta e cinco volumes. 5a edição. Moscou: Progresso, 1986, v.37.

LENIN, V. I. Acerca da chamada questão dos mercados. In Obras completas em cinqüenta e cinco volumes. $5^{\text {a }}$ edição. Moscou: Progresso, 1981, v. 1.

LENIN, V. I. Quem são 'os amigos do povo' e como luta contra os social-democratas. In Obras completas em cinquienta e cinco volumes. $5^{\text {a }}$ edição. Moscou: Progresso, 1981, v. 1.

LENIN, V.I. Nosso programa. In Obras completas em cinqüenta e cinco volumes. $5^{\text {a }}$ edição. Moscou: Progresso, 1981, v. 4.

LENIN, V. I. Que tratamos de conseguir? In Obras completas em cinqüenta e cinco volumes. $5^{\text {a }}$ edição. Moscou: Progresso, 1982, v. 9.

LENIN, V. I. O sentido histórico da luta no seio do partido na Rússia. In Obras completas em cinqüienta e cinco volumes. $5^{\text {a }}$ edição. Moscou:Progresso, 1983, v. 19.

LENIN, V. I. Conferência sobre o tema: o proletariado e a guerra. In: Obras completas em cinqüienta e cinco volumes. $5^{\text {a }}$ edição. Moscou: Progresso, 1984, v. 26.

LENIN, V. I. Variante do projeto de resolução dos social-democratas de esquerda para a primeira conferência socialista internacional. In: Obras completas em cinqüenta e cinco volumes. $5^{\text {a }}$ edição. Moscou: Progresso, 1984, v. 26. 
LENIN, V. I. Resposta às perguntas de um periodista norte-americano. In: Obras completas em cinqüienta e cinco volumes. $5^{\text {a }}$ edição. Moscou: Progresso, 1984, v. 39.

LENIN, V. I. Saudação aos comunistas italianos, franceses e alemães . In: Obras completas em cinqüenta e cinco volumes. $5^{\text {a }}$ edição. Moscou: Progresso, 1984, v. 39.

LENIN, V. I. VII congresso dos sovietes de toda a Rússia. In: Obras completas em cinqüenta e cinco volumes. $5^{\text {a }}$ edição. Moscou: Progresso, 1984, v. 39.

LESSA S, Marxismo e ética. Revista Crítica Marxista nº 14. São Paulo: Boitempo, 2002.

MANDEVILLE, B. La fabula de lãs abejas o los vícios provados hacen la prosperidad pública. México: Fondo de Cultura Económica. 1982.

MARTINS, M. F. Conhecimento e disputa pela hegemonia. In: LOMBARDI, J. C. e SAVIANI, D.(Org.) Marxismo e educação / debates contemporâneos. Campinas: Autores Associados, 2005.

SAVIANI, D. Educação socialista, pedagogia histórico-crítica e os desafios da sociedade de classes. In: LOMBARDI, J. C. e SAVIANI, D. (Org.) Marxismo e educação / debates contemporâneos. Campinas: Autores Associados, 2005.

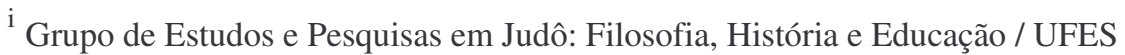
Grupo de Estudos e Pesquisas História, Trabalho e Educação / HISTEDBR

Grupo de Estudos e Pesquisas Marxismo, História, Tempo Livre e Educação / UEL

ii Para Lenin, n'O Estado e a Revolução, a mais democrática das repúblicas burguesas continua sendo uma ditadura sobre a classe operária.

iii LENIN, 1986, v. 37, p. 79

iv LESSA, 2002, p. 104

${ }^{v}$ LESSA, 2002, p. 109

${ }^{v i}$ COGGIOLA, 2002, p. 116

${ }^{\text {vii }}$ LENIN, 1981, v. 1, p. 96

viii LENIN, 1981, v. 1, p. 103

${ }^{\text {ix }}$ LENIN, 1981, v. 1, p. 179

${ }^{x}$ Figura em que se combinam palavras de sentido oposto que parecem excluir-se mutuamente, mas que, no contexto, reforçam a expressão (p.ex.: obscura claridade, música silenciosa).

${ }^{x i}$ Enfase expressiva resultante do exagero da significação lingüística; por exemplo: morrer de medo, estourar de rir.

xii LENIN, 1984, v. 26, p. 29

xiii LENIN, 1984, v. 26, p. 152

${ }^{\text {xiv }}$ LENIN, 1984, v. 26, p. 192

${ }^{\mathrm{xv}}$ A resistência do povo vietnamita nos anos 60 e 70 do século XX e do povo iraquiano no final do século XX e inicio do século XXI aos mesmos invasores, hordas de bárbaros de anglo-saxões ou apenas de norteamericanos, são exemplos claros de que as colocações de Lenin permanecem por demais corretas (LENIN, 1984, v. 26, p. 192).

${ }^{x v i}$ LENIN, 1984, v. 26, p. 193

xvii LENIN, 1984, v. 26, p. 239

xviii Lenin antecipa a mundialização do capital, o imperialismo ou seu eufemismo, cunhado pelos ideólogos da burguesia no último quartel do século XX, a globalização.

xix Esta afirmação foi confirmada na "Variante do Projeto de Resolução" tal como está grafada no texto em tela (LENIN, 1984, v. 26).
} 
${ }^{\mathrm{xx}}$ LENIN, 1984, v. 26, p. 299

${ }^{x x i}$ LENIN, 1984, v. 26, p. 300

xxii LENIN, 1984, v. 26, p. 410

xxiii LENIN, 1984, v. 26, p. 321

${ }^{x x i v}$ LENIN, 1984, v. 26, p. 323

${ }^{\mathrm{xxv}}$ LENIN, 1984, v. 26, p. 349

xxvi LENIN, 1984, v. 26, p. 362

xxvii LENIN, 1984, v. 26, p. 375

xxviii LENIN, 1984, v. 26, p. 377

xxix LENIN, 1984, v. 26, p. 377

${ }^{\mathrm{xxx}}$ LENIN, 1984, v. 26, p. 378

${ }^{x x x i}$ LENIN, 1986, v. 39, p. 399

xxxii LENIN, 1983, v. 27, p. 319

xxxiii LENIN, 1983, v. 27, p. 327

${ }^{x x x i v}$ LENIN, 1983, v. 27, p. 330

${ }^{x x x v}$ LENIN, 1983, v. 27, p. 325

xxxvi LENIN, 1983, v. 27, p. 327

xxxvii LENIN, 1983, v. 27, p. 332

xxxviii LENIN, 1983, v. 27, p. 342

xxxix LENIN, 1983, t. 27, p. 360

${ }^{\mathrm{xl}}$ LENIN, 1983, t. 27, p. 370

${ }^{x l i}$ LENIN, 1983, t. 27, p. 376

xlii LENIN, 1983, t. 27, p. 382

xliii LENIN, 1983, t. 27, p. 399

xliv LENIN, 1981, v. 1, p. 358

${ }^{x l v}$ LENIN, 1986, v. 39, p. 123

xlvi LENIN, 1986, v. 39, p. 404

xlvii LENIN, 1986, v. 37, p. 509

xlviii LENIN, 1986, v. 37, p. 510

${ }^{\text {xlix }}$ LENIN, 1983, v. 19

${ }^{1}$ MARTINS, 2005. p. 152

${ }^{\text {li }}$ MARTINS, 2005, p. 152

lii LENIN, 1986, v. 39, p. 228

liii BALIBAR, 1995. p. 34

liv CASSIM, 2005. p. 170

${ }^{\text {lv }}$ DUARTE, 2005. p. 205

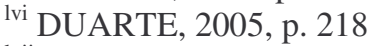

${ }^{\text {Ivii }}$ MANDEVILLE, 1982, p. 190

Iviii SAVIANI, 2005. p. 256

${ }^{\text {lix }}$ SAVIANI, 2005, p. 256

${ }^{1 x}$ SAVIANI, 2005, p. 256

${ }^{1 \times i}$ LENIN, 1981, v. 4, p. 196

Ixii LENIN, 1982, v. 9, p. 6

Ixiii LENIN, 1982, v. 9, p. 7

${ }^{\text {Ixiv }}$ FREIRE e SHOR, 1987, p. 40

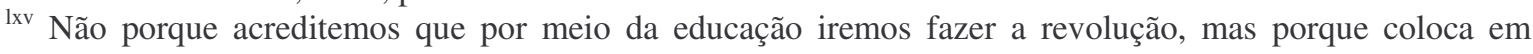
cheque os fundamentos da educação autoritária, diretiva ou não diretiva, a burguesia; e sobretudo, porque entendo a educação como instrumento, em certo momento, a serviço da classe operária, pode colocar como mecanismo político à transformação da sociedade ou como linha de ação, a via insurrecional total, a revolução socialista.

lxvi É preciso muito cuidado na utilização mecânica das afirmações e das ações, isto porque, mesmo no movimento dos sem-terra - considerado o movimento de maior envergadura progressista dos últimos anos neste país, ainda ali a educação física pode ser reacionária, como a exemplo de um certo projeto "pedagógico" transitado na UFES, mas não julgado, a promover competição entre os assentados.

lxvii O discurso liberal proposto pela Economia Política Clássica, que tem em Adam Smith e David Ricardo seus mais altos luminares, afirma a possibilidade de construção de um homem e uma cultura universais tão apenas sob a total liberdade das livres forças do mercado capitalista, quer dizer, sem nenhuma intervenção 
externa ou do Estado. Estranha coincidência, mais de um século depois, em 1987, esse discurso é resgatado [e posto como se fora "neo", embora seja "pré"] pelos ideólogos do neoliberalismo ou do imperialismo do final de século.

lxviii Contradição nos termos, tal como um cristão burguês ou marxista não militante.

lxix O contrário, o oposto, aqui usado como antagônico. Para os nossos propósitos, a concepção de mundo ou o indivíduo, em relação a outra ou o outro no campo político, se encontra em ligar diametralmente oposto: esquerda e direita define bem nossa intenção.

Artigo recebido em: 13/12/2008

Aprovado para publicação em: 15/01/2009 